\title{
The Practice of International Search and Rescue in Haiti
}

\author{
SÁFÁr Brigitta - MuHOrAy Árpád ${ }^{1}$
}

\begin{abstract}
A powerful earthquake rocked Haiti on 12th January in 2010. The earthquake, according to experts - was stronger than had been observed for 200 years in the region. The world reacted immediately to the disaster. Global humanitarian assistance launched, in order to help Haiti's population. In the first phase of the assistance rescuers had to find survivors trapped under the rubble and had to save them from there. These tasks were handled by USAR teams arriving to the area according to UN INSARAG policies. The authors examine the possibilities of the practical application of INSARAG in Haiti. This study presents the advantages and disadvantages experienced during search and rescue work and explores the possibilities of further developments.
\end{abstract}

\section{Introduction}

According to the data of u.S. Geological Survey (uSGS) the earthquake occurred on 12th January, on the mainland, 25 kilometres near to Port-Au-Prince in a west-southwest direction, in a 10 $\mathrm{km}$ nest depth, at 16:35 (local time), along the Enriquillo-Plantain Garden Fault. The intense, 7 magnitude quake according to the richter scale, caused huge disaster in and around the capital city. In the following one and a half months (between 12th January and 23d February) uSGS registered 59 after-shocks stronger than 4.5, of which 16 were larger than 5.0. One of the two biggest after-shocks was a 6.0 magnitude, and occurred 7 minutes later than the earthquake. The other, 5.9 magnitude quakes happened on the $20^{\text {th }}$ January. According to the official data 97294 buildings collapsed and 188,383 were damaged, 222,570 people died, 300,572 were injured and 2,3 million became homeless. According to the estimations the losses reached 8 billion dollars.

Examining the international response given to a natural disaster we cannot ignore an analysis of the country's internal and external relations. In case of international operations it does matter whether the given country is able to take minimal measures in order to protect the population, search for and save survivors. In the case of Haiti it is particularly true. Studying the circumstances of the country we can see a rather sad picture in view of the administrative, political conditions which derive from the history of Haiti.

\section{Historical and political background of Haiti}

In the history of Haiti centuries old internal conflicts have resulted in an undeveloped country in every respect. Native Indians were exterminated by Spanish colonizers in the 25 years after the debarkation of Colombus. The French appeared in the beginning of the $17^{\text {th }}$ century and acquired the west third of the island of 'Hispaniola' (Haiti) from the Spanish in 1697. The richness of the French colony was based foremost on forestry and the sugar industry. At the end of the $18^{\text {th }}$ century Haiti's almost half million slave population started a rebellion which resulted in the first black republic in the world, founded in 1804.

1 Email: brigitta.safar@voroskereszt.hu 
Most of the history of Haiti was characterized by political violence whereupon it is the poorest state in the western hemisphere. Due to the crisis of the presidential election in 2000 preceded by the three decades of military dictatorship Haiti has still not managed to overcome the difficulties. ${ }^{2}$

There were 32 putsches in the last decade until 2008. Therefore the leaders holding authority paid almost no attention to the development of the country, they sought after power instead. The economy of the country currently depends on international support. „René Préval, democratically elected president of Haiti (2004) confessed himself that he has very little true power, as the country is controlled by the World Bank Group and the International Monetary Fund." " Haiti covered more than half of the government's expenses from these sources in 2000. In this kind of environment the administrative reforms, and putting the country on the orbit of development is almost impossible. From the aspect of disaster management there can be no wonder if the country's own administrative and non-existing defensive systems are not able to prepare for and react to the natural disasters.

The sanitary emergencies and natural disasters can cause bigger destruction under these circumstances. ${ }^{4}$ In a young democracy like this an administration, which does not work well or does not work at all, has as a result that most of the population is defenceless against natural disasters.

The official army of the country was demobilized after the democratic elections, only a few coast-guards and a smaller police force remained as an armed body. The uN's peacekeepers have been working for the country's stability and safety recently within the scope of MINuSTAH (united Nations Stabilization Mission of Haiti). Along with the uN's forces the International Committee of red Cross (ICrC), as a representative of humanitarian rights, tries to support the population with smaller missions.

\section{Earthquake in Haiti}

Haiti's difficulties do not end with the political-economic problems. Haiti lies on the border of the Caribbean plate and is located along the Central-American hurricane zone. As a result natural disasters such as tropical storms, hurricanes, earthquakes and floods are regular.

According to the EM-DAT's (The International Disaster Database) charts more than 228 thousand people died due to natural disasters in the past decade, and these disasters affected more than 4 million people. To sum up we can say that from the aspect of disaster management Haiti is not able to perform independently in connection with preparedness, reaction, and restoration.

The earthquake, that occurred in 2010, caused far more damage in this country than ever. The world immediately reacted. In the first few days and weeks a remarkable number of organizations arrived with enormous human resources and logistics in order to help the rescue and aid of the population. After the assessment, necessary for applying international forces, the most important things to do, as always in cases of disaster, were connected to rescuing and saving human lives. These are, for instance, searching for survivors, taking care of injured ones, setting up field-hospitals and checkpoints with basic medical help; creating and coordinating temporary accommodations and camps; supplying populations with food, clean water, and essential tools for everyday life. At the same time it is very important to inform the population and public opinion and to protect the public order. ${ }^{5}$

\footnotetext{
2 KOVÁCS-SZIGETI (2006) p. 212.

3 KérI

4 WHO: Haiti health profile. http://www.who.int/gho/countries/hti.pdf (06.10.2012.)

5 IFrC. http://www.ifrc.org/Global/Publications/disasters/208400First\%20anniversary\%20Haiti\%20 EQ\%20operation\%20report_16b.pdf (28.04.2011.)
} 


\section{The INSARAG guidelines}

The head of the international aid operation was the uN's different professional organizations, which were responsible for supervising the special fields. The search, rescue and mobilization, for instance, were coordinated by OCHA and UNDAC.

In the course of interventions and the accomplishment of tasks the INSArAG principles were normative. In order to understand the tasks in general in connection with Haitiit it is necessary to review the responsive organizations according to the principles to which, as I will unfold later, new experience was added by the earthquake of $12^{\text {th }}$ January.

UN's Office for the Coordination of Humanitarian Affairs (OCHA) is the secretariat of ISArAG's ruling committee. Its function is to control and coordinate international support in case of disaster or humanitarian crisis. These activities consist of coordinating other organizations along with their own units and teams, as well.

Throughout the execution of tasks, OCHA collaborates closely with the given country's Local Emergency Management Agency (LEMA) which is the lowest controlling body and supervises the immediate actions. LEMA cooperates with united Nations Disaster Assessment and Coordination (UNDAC). The first function of the group is supporting the local forces in reacting to the disaster. It also helps to coordinate (including uSAr teams), to purchase necessary equipment, and it controls the setup of OSOCC.

On the strength of coordinating and controlling groups' work International uSAr teams do the search and rescue tasks. The teams work alone or collaborate with other teams. In the case of a given international intervention the uSAr teams will arrive at the $\mathbf{r D C}$ if that is set up. rDC is a kind of entrance, the point of the damage zone where newcomers can get informational support about the state of local emergency management.

On-Site Operations Coordination Centre (OSOCC) is the platform of cooperation between international forces and LeMA. Its setup is the responsibility of UNDAC or the first USAR team that arrives at the scene. Its main purpose is to help LEMA in humanitarian questions and coordinating international and national forces. If the damage zone requires it one main and other minor OSOCC centres can be erected. There is a web-based informational platform connected to OSOCC (Virtual OSOCC) its first aim is to ensure fast communication between the damaged country and the supportive agencies. The main purpose of INSARAG's teams is the assurance of efficient and effective intervention on both national and international levels. In order to do that, however, certain stages of intervention and the duties they contain are very important factors.

Preparation Stage - involves the time period between disasters when the formerly acquired experiences are elaborated and evaluated; essential modifications and corrections are made towards SOP; training sessions are put in progress and future operations are planned.

Mobilization Stage - consists of events after the natural or civilization disaster and includes alarming, mobilizing and sending the international uSAr teams to the damaged countries.

Operational Stage - any operations which contain the arrival of international uSAr teams to the $\mathrm{rC}$ and its registration; meeting of team leaders and orientations in OSOCC; reports to the disaster management agency of the sending country; uSAr operations in the damage zone until the Operational Stage finishes.

Demobilization (withdrawal) Stage - includes the time period when uSAr teams stop their activities in the damage zone, hand in the reports to international and national authorities, and start preparing to go home. The withdrawal of the teams is coordinated by the OSOCC from the damaged country to rDC. 
Post-operational Stage - time period after uSAr operations are closed; when uSAr teams arrive home, reports and financial reports need to be written about the mission. These summaries should consist of an empirical overview which can develop the efficiency of the cooperation in the future. ${ }^{6}$

Preparing for each stage can bring a successful intervention. In case of Haiti the first USAR team arrived at the scene in less than 24 hours which can be considered really fast. Based on the foregoing I will review the circumstances of international responses to the earthquake of $12^{\text {th }}$ January 2010 from the aspect of INSArAG principles.

\section{Search and rescue operations in Haiti - INSARAG into practice}

The first signal of the natural disaster arrived at 23:05 (GMT+1, according to Geneva's time) to OCHA. Soon after that uN's INSArAG mobilization order was activated. The possible member list of uNDAC team, which arrived at Port-au-Prince on 13th January, was ready at 23:40. The primary task was to estimate the needs and to make the plan of action, which provided support and control for the local humanitarian coordinator. Cooperating with local organizations and following the INSArAG principles the structure, shown by the illustration evolved.

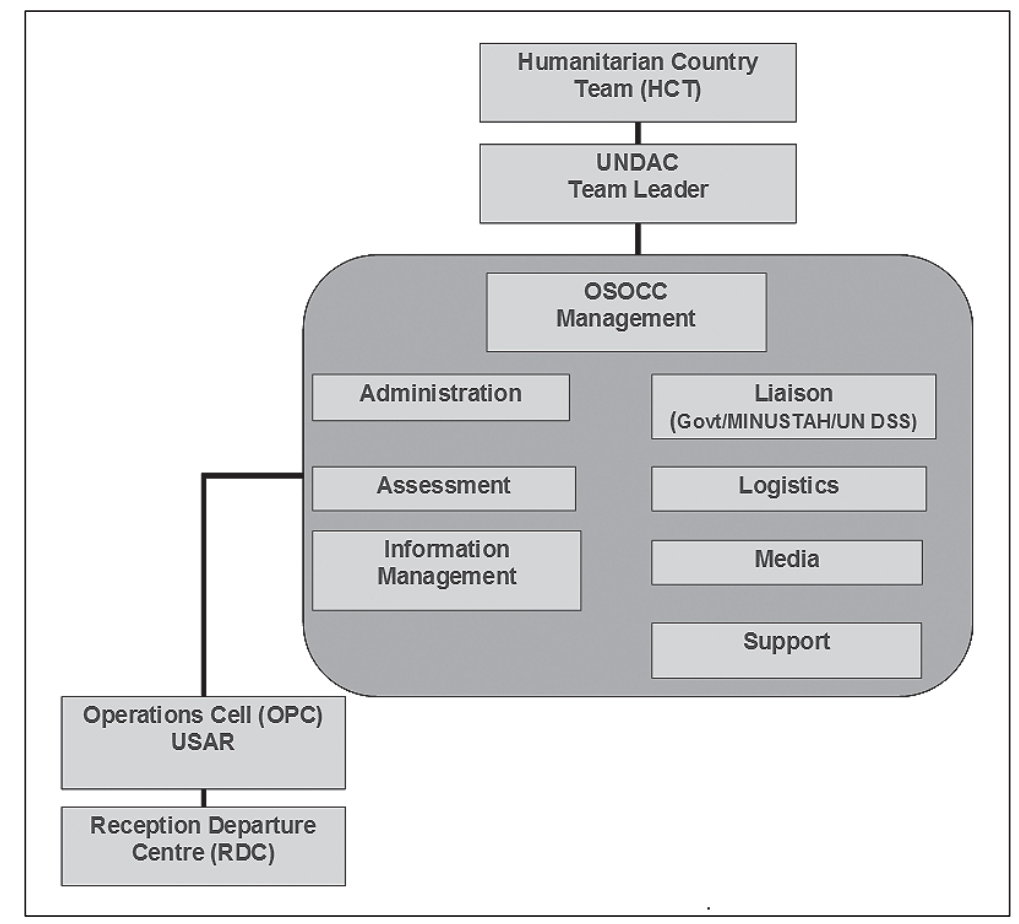

Figure 1. The structure of international intervention in Haiti

(Source: UNDAC MISSION REPORT Haiti Earthquake, January 2010; page 6.)

6 OCHA: INSArAG Guidelines. http://www.insarag.org/images/stories/INSArAG_Guidelines_and_ Methodology_2011_edition_Hungarian_translation.pdf 
In order to welcome the international forces rDC (later OPC) was established on the seriously damaged Port-au-Prince airport. As a result of the area's conditions it was perfectly capable of creating a base for uSAr teams because the airport was suitably surrounded by walls and was protected by military. Due to the limited capacity the airport and the numerous teams arriving, another base at Santo Domingo was established by rCD. OSOCC was instituted at united Nations Stabilization Mission in Haiti (MINuSTAH) which is about 2 kilometres away from the airport so the distance did not cause any problem. ${ }^{7}$

First reports on the earthquake contained the information that several high buildings including hospitals, schools, hotels and blocks of flats collapsed. These buildings were at the top of the RCD priority list with reference to search and rescue tasks. First the uSAr teams started working at these buildings.

42 blocks were formed in the region of Port-au-Prince which covered 63 square kilometres. Teams, qualified as advanced ones by INSARAG, were directed to the most affected areas. Then, as teams continuously arrived and there were enough advanced, medium and easy teams available , teams were ordered to fields according to each sector's priority listing. Theory was based on assessing each sector in order to define priorities. each team got to their area at 6 o'clock in the morning and was asked to keep in touch with OPC all day. Then every evening at 19:00 team leaders discussed the events of the day, gave in their reports, and their analysis led to the tasks of next day. ${ }^{8}$

According to the air reconnaissance it was brought to light in the first week that suburban areas need uSAr teams as well despite the fact that there were no high buildings. uNDAC groups needed to handle urgent humanitarian emergencies along with search and rescue tasks in these areas since most of the survivors here spent everyday in the open air. Search and rescue tasks were helped by alternative information channels. Survivors trapped under the ruins gave signs of life via messages or phone calls by which the teams could start rescuing them after a cross-check. In this respect there is an interesting fact. Some teams wanted to communicate with OPC through satellite phones but since every representative of the media used this technical bandwidth it was saturated and teams could not report to OPC. This caused a problem in public security because the teams could not report the threats either.

Besides the security threats, providing devices and fuel for conveying the teams involved difficulties, as well. Local government could not provide resources properly so UN's MINUSTAH forces accomplished the logistic duties.

\section{Summary}

Despite the difficulties 50 USAR teams from 30 nations with 1800 people and 160 dogs took part officially (between $14^{\text {th }}-22^{\text {th }}$ January) in the operations in the search and rescue stage.

As a result it can be set up that the following lessons can be learnt from the Haiti-intervention with regard to the further development of the search and rescue methodology:

- virtual OSOCC is an excellent platform for fast information flow. Although development and applying information technology equipment should not be disregarded. For real-time voice-transmitting Skype is excellent, which for example, allows people from different places of the world to make conference calls.

7 uNDAC MISSION rEPOrT Haiti Earthquake, January 2010

8 Ibibd. 
- as long as the disaster occurs in a high security risk area it is expedient to include a person from the UNDAC group from the uN's DSS team.

- in case of such huge disasters, contacting and staying in contact with local authorities is pivot- al. Sharing information with the humanitarian community is also crucial.

- with respect to the INSArAG methodology this disaster was instructive, among other things it taught us if an INSARAG methodology can be established in other humanitarian fields or not.

- in case of every disaster which affects large populations NGOs also arrive at the area with whom coordination is needed to be supervised as well in order to avoid initial chaos.

\section{References}

IFrC. http://www.ifrc.org/Global/Publications/disasters/208400First\%20anniversary\%20Haiti\%20 EQ\%20operation\%20report_16b.pdf (28.04.2011.)

KérI András, dr.: Haiti és a fehér ember történelme. http://web.kvif.bgf.hu/upload/menu_content/ doc/20100920150535X_NyV9_KeriA2.pdf (28.04.2011.)

KOVÁCS Péter - SZIGETI Borbála (2006): Földrajzi Világatlasz. Cartographia Kft, Budapest. OCHA:

INSArAG Guidelines. http://www.insarag.org/images/stories/INSArAG_Guidelines_and_

Methodology_2011_edition_Hungarian_translation.pdf uNDAC

MISSION rEPOrT Haiti Earthquake, January 2010

WHO: Haiti health profile. http://www.who.int/gho/countries/hti.pdf (06.10.2012.) 